УДК 58:069.029(477)

(C) 2013

Колесніков Л. О., кандидат біологічних наук

Полтавська державна аграрна академія

Колеснікова О. Л., віце-президент

Громадське об'єднання «ЕКОС»

\title{
ФЛОРА СПОЛУЧЕНИХ ШТАТІВ АМЕРИКИ ТА СУМІЖНИХ КРАЇН ПІВНІЧНОЇ АМЕРИКИ У ДЕНДРОПАРКУ ПОЛТАВСЬКОЇ ДЕРЖАВНОЇ АГРАРНОЇ АКАДЕМЇ̈
}

\section{Рецензент - кандидат сільськогосподарських наук М. М. Маренич}

Проведено еколого-географічний аналіз дендрофлори парку Полтавської державної аграрної академії-розподіл флори парку за географічним розповсюдженням. Виконані: генетичний аналіз розподіл флори за критеріями географічного походження й історії розселення; ботанікогеографічний аналіз - встановлення зв 'язків даної флори з іншими флорами. Виділено рослини, щчо походять із Північноамериканського регіону. Наведено екологічний стандарт цих рослин: вказані їх вимоги щуодо едафічних чинників середовища, умов освітленості, температури, фітопатологічна стійкість. Зроблено еколого-фітоценологічний аналіз - розподіл флори за умовами зростання.

Ключові слова: дендрофлора, Північноамериканський регіон, екологічні чинники середовища, дендрологічні парки, едафічні чинники.

Постановка проблеми. 3 року в рік вимоги до якості озеленення міських територій значно зростають. Крім того, внаслідок глобальних змін клімату, стали іншими як температурний режим, так і умови зволоження. В останні десятиліття середньорічні температури суттєво підвищилися: звичайною вже стала відсутність постійного снігового покриву протягом усієї зими, значно виросла аридизація клімату (тобто його опустелювання). Пікові літні температури наблизилися до $+40{ }^{\circ} \mathrm{C}$; до того ж така температура зберігається протягом тривалого часу. Все це вимагає пошуку нових рослин, які за таких умов можна було б використовувати в озелененні міських ландшафтів.

Аналіз основних досліджень і публікацій, у яких започатковано розв'язання проблеми. Полтава - піонер у створенні ботанічних садів в Україні. Перший ботанічний сад було закладено тут ще у 1805 році [2]. Традиції парконасадження у Полтаві підтримувалися постійно, і у середині XX століття Полтава вважалася одним із найзеленіших міст України [1]. У зв'язку зі змінами кліматичних умов і появою нових карантинних фі- топатологічних об'єктів окремі деревні породи, що використовуються для озеленення, виявилися непридатними для цього. Наприклад, карантинний шкідник каштанова міль настільки пошкоджує головну породу, що традиційно використовувалася в озелененні (каштан кінський), що вона повністю втратила свою декоративність і потребує заміни. Багато видів деревних порід, які ушкоджуються омелою, також втратили своє значення в озелененні ландшафтів, оскільки ця паразитична рослина вкрай важко піддається ефективному знищенню.

Екзотичні деревні породи, які потенційно можна використовувати в озелененні ландшафтів в Україні, частіше розглядаються у географічній літературі. Особливу цінність набувають дані про те, як ці деревні породи почувають себе в умовах Полтавщини. Накопичений протягом останніх десятиліть досвід вирощування екзотів дає змогу оцінити їх придатність для використання в озелененні у лісостеповій зоні України.

Мета і завдання дослідження. Метою дослідження $\epsilon$ географічний аналіз флори дендропарку Полтавської державної аграрної академії, аналіз вимог щодо екологічних чинників середовища елементів північноамериканської флори дендропарку.

Завдання дослідження: флористична діагностика дендропарку Полтавської державної аграрної академії.

Методи дослідження:

- географічний аналіз флори - розподіл флори за географічним розповсюдженням;

- ботаніко-географічний аналіз - встановлення зв'язків даної флори з іншими флорами;

- еколого-фітоценологічний аналіз - розподіл флори за умовами зростання.

Результати дослідження. Кліматичні умови Американського континенту відрізняються значною різноманітністю, що робить теоретично можливим виокремити 3 дендрофлори цього регіо- 
ну види, акліматизація яких може успішно проходити і в лісостеповій зоні України. Для цього необхідно провести відповідний аналіз грунтових умов, температурного режиму в осередках формування видів, що викликають інтерес із точки зору зеленого ландшафтобудування та озеленення урбанізованих територій. Надзвичайне різноманіття вологості й температурних умов Північної Америки сформувало деревні спільноти $з$ широким спектром адаптивних можливостей. Уся північ Тихоокеанського узбережжя Північної Америки знаходиться під впливом теплої течії. Прогріті у тропічній зоні маси теплої води підхоплюються Північною Пасатною течією та Курасіо, обігрівають східну частину Азіатського континенту, від широти південних Курил перетинають Тихий океан і виходять до західного узбережжя Північної Каліфорнії, Канади й Аляски. Пролітаючи над Аляскою вздовж узбережжя на південь у бік Каліфорнії, ми спостерігали, як швидко морські льодові глиби, що виносилися через протоку Берінга з Льодового океану в Тихий, потрапивши у води теплої течії, починають танути й зникати. Над теплою водою у Тихому океані формуються маси теплого вологого повітря, які постійно західними вітрами виносяться на континент i випадають у вигляді дощів. Кількість опадів на Тихоокеанському узбережжі Канади (в районі Ванкувера) вдвічі перевищує цей показник для Полтави (569 мм), досягаючи 1199 мм на рік. Цьому сприяє також те, що вздовж Тихоокеанського узбережжя (особливо у його канадській частині) тягнуться високі хребти, прорізані вузькими глибокими долинами. Зіткнувшись із цими горами, вологі повітряні маси піднімаються вгору, де охолоджуються. Відбувається інтенсивна конденсація вологи, і на західних, звернених до океану схилах, спостерігаються значні опади. За таких умов формуються вологі дощові ліси тихоокеанського типу помірного поясу. Вони представляють третинну дендрофлору, яку не змогли знищити льодовики. Реліктові ліси Тихоокеанського північно-західного регіону Америки за продуктивністю і розмаїттям видів - найкращі в світі. Запаси древесини незайманих лісів іноді сягають 6 тис. м ${ }^{3}$ на гектар. Під час останнього обледеніння меридіальне розташування гірських пасм і лісорослинних зон, зумовлене меридіальним розташуванням берегових хребтів, дало змогу рослинності відступати перед льодовиками на південь, а 3 часом знову повернутися на звільнені території. Це й спричинило збереження рідкісних лісових видів, збільшило їхню пластичність. Саме вони є батьківщиною гігантів із-поміж деревних рослин. Так, окремі екземпляри секвойі (Sequoia sempervirens) (ін. назви: секвойя тисовидна, червоне дерево) сягають висоти понад 110 метрів. Це одні $з$ найвищих дерев на Землі. Їх максимальний вік - понад три 3 половиною тисячі років. Деревні породи Тихоокеанського узбережжя Північної Америки - рекордсмени нашої планети 3 тривалості життя серед живих організмів.

Із деревних рослин цього регіону на території дендропарку Полтавської державної аграрної академії росте псевдотсуга Мензіса (Pseudotsuga menziesii Franco), відома також як лжетсуга Мензіса, nсевдотсуга тисолиста, орегонська сосна, дугласія тисолиста, дугласова ялиця, дугласова ялина (від імені шотландського ботаніка Д. Дугласа, D. Douglas; 1798-1834). Росте на заході Північної Америки, утворюючи величезні лісові масиви вздовж усього узбережжя Тихого океану від Британської Колумбії до Каліфорнії, в Монтані, Колорадо, Техасі і Нью-Мексіко. На висоті 6002900 м утворює як чисті насадження, так і змішані хвойні ліси (із туєю гігантською, тсугою різнолистною, ялиною сітхінською, ялицею великою). Дугласія - могутнє, красиве вічнозелене дерево, що досягає висоти 100 м за товщини стовбура до 4 метрів. Має понад 10 видових різновидів і безліч сортових форм, зокрема багатостовбурних, компактних, із сизою і сизо-зеленою хвоєю. Як природні, так і сортові різновиди не лише надзвичайно морозостійкі, але і не страждають від весняного сонця. Псевдотсуга сиза, що часто виділяється в окремий вид, у порівнянні 3 береговою формою псевдотсуги Мензіса, що росте на узбережжі Тихого океану, має гірське походження (Скелясті гори США) [6]. Вона не досягає такої значної висоти, як берегова форма, висота псевдотсуги сизої на батьківщині становить не більше 40-50 м, зате вона менш вибаглива і більш холодостійка, тому добре росте навіть у північніших районах. Псевдотсуга Мензіса - тіневитривала, посухостійка порода, маловимоглива до родючості грунту, хоча краще росте на добре дренованих суглинках; погано росте на болотистих, бідних піщаних і важких глинистих грунтах. Росте швидко. Живе до 400 років.

Із деревних рослин цього регіону на території дендропарку Полтавської державної аграрної академії зустрічаємо також магонію падуболисту, або орегонський виноград (Mahonia aquifolium Nutt.). Ареал виду охоплює західні штати Північної Америки - від Британської Колумбії до Каліфорніі. Вічнозелений чагарник заввишки близько метра. Утворює зарості через розростання 
кореневими відростками. Кора на молодих пагонах рожево-сіра, верхівкова квіткова брунька яйцевидна, довжиною близько сантиметра. Листя - складне, непарноперисте, завдовжки 15-20 см, черешок зазвичай червонуватий; листочки шкірясті, зверху темно-зелені, глянцеві, з мережею жилок, знизу матові, блідо-зелені, по краю виямчато-гострозубчасті. Квітки в діаметрі близько 8 мм, зібрані в багатоквіткові волоті або кетяги жовтого кольору. Плоди - довгастоеліптичні ягоди, завдовжки до 10 мм, шириною 8 мм, синювато-чорні, з густим сизим нальотом. Більшість магоній надають перевагу півтіні, але ростуть i на сонці. Ці рослини вимогливі до грунтів: надають перевагу кислим або нейтральним, багатим на гумус суглинкам. Рослини хоча й вологолюбиві, проте погано переносять застій води. У холодні зими, й особливо під час повернення холодів на початку весни, можуть обмерзати вище рівня снігу. У нашій кліматичній зоні магонії не ушкоджуються комахами.

Із деревних рослин Тихоокеанського регіону на території дендропарку Полтавської державної аграрної академії росте також туя складчаста, або туя гігантська (Thuja plicata Donn.). У природі ареал виду охоплює північний захід Північної Америки, передусім берегову смугу Тихого океану від Аляски до північної Каліфорнії. Дерева заввишки 45-60 (до 75) метрів і діаметром стовбура 120-240 см, із пірамідальною або конічною кроною, горизонтальними гілками й декількома звисаючими, плоскими пагонами. Кора - 3 тріщинами, волокниста, червонувато-коричнева, завтовшки 1-2,5 сантиметри. Росте чистими насадженнями або разом 3 іншими видами. Зустрічається на низовинних заболочених місцях, берегах річок, поблизу моря, де сягає найбільших розмірів. У горах росте на тіньових схилах. На межі розповсюдження переходить у чагарникову форму. До грунтів маловибаглива, хоча краще всього розвивається на вологих родючих добре дренованих грунтах. Тіневинослива. Тривалість життя рослини - 500-800 років.

Зовсім інші кліматичні умови склалися на східних схилах Кольдер'єр та плоскогір'ях, що знаходяться за ними. Повітряні маси, надходячи сюди із заходу, вже віддали свою вологу у вигляді опадів, піднімаючись західними схилами. Перейшовши через Кольдер'єри, вони опускаються, стискаються й нагріваються. Ці фізичні процеси ще більше висушують повітря - тому тут сформувалися кам'янисті напівпустелі з нечастими опадами й тривалим спекотним літом. За таких умов сформувалися деревні породи, представлені у дендропарку Полтавської державної академії ялиною блакитною, колючою (Рісеа pungens Engelm.). У природних умовах цей вид зустрічається на північному заході США (штати Юта, Колорадо, Арізона і Нью-Мексіко) на висотах 1750-3000 метрів. Росте в гірських долинах уздовж річок і струмків, де грунт вологіший. Ялина блакитна - вічнозелене хвойне дерево заввишки 25-30 м, іноді - до 46 метрів. Діаметр стовбура - до 1,5 метра. Кора - тонка, лускова. Крона у молодих дерев - вузькоконічна, у старих стає циліндровою. Хвоя - завдовжки 15-30 мм, у розрізі має ромбічну форму. Колір голок - від сірувато-зеленого до яскраво блакитного. В умовах низьких температур блакитна ялина приживається погано, насіння майже не дає. До грунтових умов невимоглива. За хороших умов хвоя зберігається на гілках 5-7 років (частіше - 3-4 роки). Світлолюбива, надає перевагу грунтам середньої родючості й вологості, проте не витримує перезволоження.

Кліматичні умови й сформована ними деревна рослинність східного узбережжя Північної Америки зовсім не схожі на умови й дендрофлору Тихоокеанського узбережжя. Холодна Лабрадорська течія несе води Льодовитого океану до східних берегів Канади та Сполучених Штатів. Над ними формуються холодні вологі повітряні маси, які охолоджують значну частину півночі континенту. До того ж сюди без перешкод проникають холодні північні вітри, що стікають із льодовиків Гренландії та прилеглих архіпелагів. Ці повітряні маси особливо переохолоджуються у період тривалих полярних ночей. Такі умови сформували широку зону тайги. Ці ліси складаються 3 деревних порід, що витримують значні морози, тривалі снігові зими, весняні холоди, ранню (вже у серпні) короткотривалу осінь. У дендропарку нашої академії ця кліматична зона представлена ялиною сизою, або білою, або канадською - Picea glauca Voss. [syn. Picea canadensis Britt.], що походить із півночі США. У лісовій зоні, часто по берегах річок і озер, утворює чисті й змішані насадження, піднімаючись у гори на висоту 1500 метрів. Дерево заввишки 20-35 м, із стовбуром 60-120 см у діаметрі, з густою правильною конусовидною щільною кроною. Гілки молодих рослин направлені вгору, у старих - переважно опущені донизу, плоскі. Кора - гладка або лускова, попелясто-коричнева. Молоді пагони жовтувато- або білувато-коричневі, голі. Рослина зимостійка і досить посухостійка. Живе близько 300-500 років. Успішно росте як у морському, так і в континентальному кліматі. Не вибаглива 
до грунтів, виносить як бідні, так і піщані грунти. Добре протистоїть вітрам, вирощується як вітрозахисна порода. До газів і диму менш чутлива, ніж ялина європейська.

«Коніка» («Conica») - найпопулярніша конічна форма ялини канадської. У віці 60 років висота дерева сягає 4 м, крона їх - чітко пірамідальна, щільна, діаметром близько двох метрів. Вперше була знайдена у 1904 році в Канаді відомими північноамериканськими дендрологами Редером і Джеком на озері Лаган, звідки і розповсюдилася в сади і парки світу. Розмножують іiі живцями; укоріняється $75 \%$ літніх живців без обробки. Тіневинослива. Мутантами ялини сизої «Коніка»є: «Альберта Глобе», «Лаурін», «Елеганс Компакта». Росте повільно - щорічний приріст становить 1,5 см; високо зимостійка.

На південь від тайги, вздовж Атлантичного узбережжя США, тягнуться ліси, зв'язані з гірською системою Аппалачі. Частину 3 них, що сформувалися навколо Великих озер, американські лісоводи назвали хвойними «озерними лісами». Від Великих озер та Адіродакських гір на півночі вони тягнуться далеко на південь, аж до зони субтропіків. Широколистяні ліси цього гірського пасма представлені типовими американськими видами: клен иукровий, бук великолистий, тюльпанове дерево [4].

У дендропарку аграрної академії дендрофлору означеної зони представляють липа американська, сосна Веймутова, або сосна біла східна, дуб червоний, туя західна, міхуроплідник калинолистий, або спірея калинолиста, ялівець вергінський, гортензія деревовидна, робінія псевдоакація, або Робінія лжеакація, або Робінія звичайна.

Сосна Веймутова, або сосна біла східна (Pínus stróbus L.) у природних умовах поширена на північному сході США (всі штати на схід від Міннесоти, Айови і Джорджіі) та південно-східних провінціях Канади (Ньюфаундленд, Квебек, Онтаріо). Зустрічаються підвиди в Мексиці й Гватемалі. На півночі ареалу росте на рівні моря, на півдні піднімається на висоту до 1500 м над рівнем моря. Дерево - 30-67 м заввишки, 100-180 см завтовшки. Стовбур - прямий. Крона - спочатку конусоподібна, далі - закруглена. Кора - світлоcipa, $з$ віком темніє, має незначний фіолетовий відтінок. Гілки - великі, мутовчаті, розходяться в сторони і злегка вгору. Хвоїнки розташовані по 5 у пучку, довжиною 6-10 сантиметрів. Надає перевагу сухим грунтам і прохолодному вологому клімату. Менш вибаглива до світла, ніж сосни звичайна i чорна. За рівнем вимогливості до вологості повітря наближається до ялини, погано переносить континентальні умови. Найкраще росте на свіжих глибоких супіщаних і суглинних грунтах. Досить страждає від пузирчастої іржі, особливо на бідних грунтах.

Липа американська (Tilia americana L.) у природі зустрічається на сході Північної Америки, листопадне дерево, що сягає висоти 20-35 (іноді - до 40) метрів із діаметром стовбура близько 1,2 метра. Крона - розлога, гілки часто нахилені донизу. Кора - сіра або світло-коричнева з вузькими тріщинами. Коріння - велике, росте вглиб і в ширину. Однорічні пагони - гладкі, червонувато-сірі, на другий рік стають світло-сірими, потім темно-коричневими або коричнево-сірими, покритими темними виступами. Бруньки розташовані щільно, загострено-овальні, гладкі, коричневого кольору, з двома криючими бруньковими лусочками. Листя - просте, почергове, овальної або серцеподібної форми, 3 довгим тонким черешком, зубчатим краєм і гострою верхівкою. Розмір листя - 10-15 см у довжину i ширину (іноді до 25 см). Молоде листя - блідо-зелене, матове, зрілий листок - темно-зелений, гладкий, блискучий зверху, знизу блідіший, 3 пучками іржаво-коричневих волосків. Невеликі прилистники невдовзі після розпускання бруньок обпадають. Осіннє забарвлення листя - від жовтозеленого до жовтого. Невеликі (10-14 мм у діаметрі), жовтувато-білі запашні квітки зібрані по 6-20 у пониклі зонтиковидні суцвіття. Білуватозелені приквітки прикріплені на середині квітконіжок. Квітки правильної форми, 3 п'ятьма пелюстками і чашолистками, численними тичинками. Цвітіння припадає на початок або середину літа. Основні обпилювачі - бджоли. Плоди округлі сухі коробочки кремового кольору, 8-10 мм у діаметрі. Липа американська, як і клен цукровий, є содомінантом кленово-липових лісів, найбільш поширених у західному Вісконсіні, центральній Міннесоті. У невеликій кількості вид зустрічається в багатьох інших лісових асоціаціях. Рясний нектар використовується різними видами комах. Насіння поїдають бурундуки, миші, білки. Полівки і кролики обгризають кору 3 пагонів, іноді ушкоджуючи молоді дерева [5].

Дуб червоний (Quercus rubra L.) зустрічається по берегах річок, де немає застою води в грунті, на північ від 35-ої паралелі Північної Америки, аж до Канади. Доросле дерево сягає 25 метрів у висоту. Дерево струнке, з густою шатровидною кроною. Стовбур покритий тонкою гладкою сірою корою, у старих дерев кора розтріскується. Листя глибоковиямчате, тонке, блискуче, до 1525 см, із 4-5-ма загостреними лопатями 3 кожно- 
го боку листка; при розпусканні - червонуваті, влітку - темно-зелені, світліші знизу, восени мають забарвлення від оранжевого до фіолетового кольору. Звичайне дерево широколистяних i змішаних лісів, надає перевагу захищеним долинам або невисоким горбам. Морозостійкий. Середньосвітлолюбний, легко переносить бічне затінювання, хоча надає перевагу повному освітленню верхівки крони. Вітростійкий, не дуже вимогливий до родючості грунту, витримує навіть кислу реакцію, проте не витримує вапняних i перезволожених грунтів. Краще росте на свіжих супісках і суглинках. Погано переносить близькість грунтових вод i засуху. Стійкий до шкідників і хвороб, у тому числі й до борошнистої роси. Має високі фітонцидні властивості.

Туя західна (Thuja occidentalis L.) у природі зустрічається в східних районах Північної Америки. Основний природний ареал - південносхідна частина Канади і північна частина США. Цей вид також зустрічається місцями і на північному заході провінції Онтаріо, в Аппалачських горах західної Пенсільванії, на півдні Північної Кароліни. Дерево росте повільно, досягаючи висоти 12-20 метрів, має компактну пірамідальну або яйцевидну крону [6]. Кора у молодих дерев гладка, червоно-бура, 3 часом стає сірокоричневою, у старих дерев відділяється вузькими подовжніми смугами. Хвоя - лусковидна, зелена, взимку буро-зелена, дрібна (0,2-0,4 см), щільно притиснута до пагона, функціонує 2-3 роки й опадає разом із дрібними гілочками (гілкопад). Верхня сторона пагонів - темно-зелена блискуча, нижня - світла матова. Розмножується як насінням (потрібна стратифікація), так і зеленими живцями. Середньовимоглива до вологості грунту, переносить засуху. Світлолюбна, проте може витримувати й невелике затінювання. До грунтової родючості маловимоглива, але надає перевагу свіжим сірим лісовим грунтам із високим вмістом кальцію. Завдяки великій кількості високодекоративних штучно виведених форм, зимостійкості, довговічності та стійкості до міських умов, туя західна досить поширена в декоративному садівництві на всіх континентах у багатьох кліматичних зонах.

Міхуроплідник калинолистий, або спірея калинолиста (Physocarpus opulifolius L.) - надзвичайно декоративний листопадний чагарник сімейства розоцвітих, походить зі східної частини Північної Америки. У природі росте по берегах річок, у підліску. Широкий округлий чагарник висотою близько 3-4 метрів. Кора на старих гілках лущиться. Листя - трьох- або п’ятилопатеве, зелене, восени не міняє забарвлення або стає золотисто-жовтим. Квітки рослин мають білий або білувато-рожевий колір, зібрані в кулясті зонтиковидні суцвіття. Цвіте міхуроплідник калинолистий у червні - липні. Плоди спочатку червоні, згодом - червонувато-коричневі. Міхуроплідник калинолистий відзначається невибагливістю до умов зростання. Рослина морозостійка, хоча в досить морозні й малосніжні зими верхівки гілок можуть підмерзати. Невимоглива до грунту, але не виносить вапняних грунтів. Важливо не перезволожувати грунт, оскільки міхуроплідник не витримує застою вологи. Відрізняється швидкими темпами росту: за вегетаційний період приріст чагарника сягає 40 сантиметрів.

Ялівець вергінський (Juniperus virginiana L.) у природних умовах росте в Північній Америці, від Канади до Флориди. Зустрічається в горах, по річкових терасах, уздовж берега океану, на скелях, рідше - на болотах. Це вічнозелені, однодомні (рідше - дводомні) дерева, в молодому віці - 3 яйцевидною кроною. Висота дерев - близько 30 метрів, діаметр стовбура - близько 150 сантиметрів. Стовбур покритий сірою, темнобурою або червоно-бурою потрісканою корою, що відшаровується, зеленою у молодих пагонів. Пагони тонкі, чотиригранні. Хвоя дрібна (0,1-0,2 см), луско- або голковидна, темно-зелена. Загальний колір листя - темно- або сизо-зелений, у зимовий період - буро-зелений. Шишкоягоди - кулясті, темно-сині, з сизим нальотом, до 0,6 см, дозрівають восени першого року (у жовтні) й довго залишаються на деревах. Росте швидко. Стійкий до шкідників і хвороб. Зимостійкий. Іноді страждає від снігових заметів. Посухостійкий. До грунту й вологи маловимогливий, але добре росте на свіжих суглинних і піщаних грунтах. У природі зустрічається й на бідних гравієвих схилах гір, уздовж берегів річок і струмків. Тіневиносливий. Коренева система стрижньова, 3 розвиненим бічним галуженням.

Гортензія деревовидна (Hydrangéa arboréscens L.) росте у східних районах Північної Америки. Швидкорослий чагарник заввишки близько трьох метрів. Квітки - дрібні, білого кольору, блискучі, 1,5-2 см у діаметрі, утворюють щитовидні суцвіття діаметром до 15 сантиметрів. Верхня сторона листка гортензії деревовидної зелена, нижня - сизувата. Рясно цвіте з чотирьох років; цвітіння тривале, з першої половини липня до жовтня. Плоди дозрівають у жовтні. Рослина вологолюбна. Добре росте в напівтіні на достатньо зволожених компостних i листових грунтах, але місце посадки повинне бути захи- 
щене від вітру. Рослина може переносити короткочасну засуху i лужний грунт. Взимку може підмерзати через те, що пагони не повністю дерев'яніють. Розмножується вегетативно [3]. Молоді і довгі пагони іноді пошкоджуються попелицею. На листі зустрічається хлороз.

Робінія псевдоакачія, або Робінія лжеакачія, або Робінія звичайна (Robinia pseudoacacia). Досить поширена ботанічна помилкова назва «біла акація». Справжня акація виглядає зовсім інакше і росте переважно в Австралії й Африці, а в європейських країнах акацію вирощують лише в оранжереях. Рослина родом із Північної Америки. Ареал охоплює Аппалачські гори від Пенсільванії до Джорджії, на захід до Айови, Miссурі й Оклахоми. Дерево псевдоакації має розлогу й ажурну крону. Квіти - дрібні, білого або рожевого кольору, ростуть кетягами, з сильним приємним ароматом. Пагони акації покриті твердими колючками завдовжки близько двох сантиметрів. Росте швидко, особливо до 10 років, щорічний приріст становить 60-80 сантиметрів. Розвиває глибоку розгалужену кореневу систему, даючи прикореневу поросль. Досить світлолюбива. Росте на будь-яких грунтах, надаючи перевагу легким і родючим, не витримує ущільнення. Витримує досить значне засолення. Швидкоросла, лісоутворююча, посухостійка порода.

\section{БІБЛІОГРАФІЯ}

1. Байрак О. М., Самородов В. М., Панасенко Т. В. Парки Полтавщини: історія створенння, сучасний стан, шляхи збереження. - Полтава: Верстка, 2007. -267 с.

2. Заповідні території України. Ботанічні сади та дендропарки / Науково-довідникове видання. Кваша В. В., Семенова О. О., Чувікіна Н. В. - К. : ТОВ «Майстерня книги», 2009. - 293 с.

3. Чувикова А. А., Потапов С. П., Коваль А. А.
Висновки. Проведені дослідження показали, що представлені у дендропарку Полтавської державної аграрної академії види з дендрофлори Північноамериканського континенту характеризуються широким спектром адаптаційних можливостей до умов середовища.

Посухостійкими, невимогливими до грунтової родючості є ялівець вергінський та ялина блакитна колюча.

Високою посухостійкістю та світлолюбивістю відзначається робінія псевдоакація.

Вологолюбними, помірно світлолюбними, iз середньою вимогливостю до грунтової родючості є сосна Веймутова, магонія падуболиста, туя західна, туя гігантська.

Дуже вологолюбними та морозостійкими, із середньою вимогливістю до грунтової родючості $€$ псевдотсуга тисолистна та ялина канадська.

Помірно стійкі до морозів, із середньою вимогливістю до умов зволоження, грунтової родючості та освітленості дуб червоний, міхуроплідник калинолистий, липа американська.

Вологолюбна, теплолюбна і вимоглива до грунтової родючості гортензія деревовидна.

Різноманітне поєднання едафо-кліматичних вимог дає можливість із деревних рослин Північної Америки вибрати придатні й оптимальні для умов конкретних територій, що $є$ запорукою їхнього успішного росту та довговічності.

[u 1980.

4. Ян Еник. Иллюстрированная энциклопедия лесов. - Прага : Артия, 1987. - С. 51-54.

5. Keeler H. L. Our Native Trees and How to Identify Them. - New York : Charles Scriber's Sons. - P. 24-31.

6. Michael Hogan. Douglas-fir: Pseudotsuga menziesii, globalTwitcher.com, ed. Nicklas Stromberg, 2008. 